\title{
Virtual water trade in industrial products: evidence from Malaysia
}

\begin{abstract}
Virtual water embodied in international trade is equivalent to nearly one-third of global water withdrawal, confirming that trade plays a significant role in redistributing global water resources. This paper extends a virtual water analysis by measuring the extent to which virtual water embodied in traded industrial products affects the distribution of global virtual water. The distribution of global virtual water can be improved if trade in industrial products promotes virtual water outflows from water-abundant to water-scarce countries. Analyses were performed using an inputï output model that can decompose water consumption into domestic demand and exports by destinations of trade. Focusing on Malaysia, the results indicate that trade in industrial products between Malaysia and its main trading partners have a limited capacity to improve the distribution of global virtual water. This limitation can be due to two reasons. Firstly, exports of Malaysian industrial products are mainly driven by less water-intensive sectors. Therefore, the amount of virtual water that outflows into other countries is also low. Secondly, trade in Malaysian industrial products largely involves water flows with other water-abundant countries. Only several water-scarce countries benefit from virtual water trade in industrial products with Malaysia, namely the Netherlands, Australia and China.
\end{abstract}

Keyword: Industrial products; Inputï output model; International trade; Virtual water; Water flows 